\title{
ECONOMICS OF ORGANIC VS INORGANIC CARROT PRODUCTION IN NEPAL
}

\author{
Raj Kumar Adhikari (MSc) ${ }^{1}$
}

\begin{abstract}
During February-April 2008, a study was conducted to compare the yield and economics of organic and inorganic carrot production and its profit volume in Chitwan district of Nepal. Face to face interview method was used to collect the primary information from randomly selected organic and inorganic carrot producers. Among the cost components, per unit cost on female labor and organic fertilizer were found to be higher in organic production system where as higher per unit cost on seed, tillage operation and male labor were found in inorganic production system. Higher cost and higher revenue was found in inorganic production system but higher benefit cost ratio was found in organic production system. This revealed that adoption of organic carrot production system was economically profitable than inorganic production system.
\end{abstract}

Key words: Benefit cost ratio, carrot, cost, gross margin, organic agriculture

\section{INTRODUCTIOIN}

In Nepal, organic agriculture is getting wider attention by government, private sector, NGOs and farmers. Previous Five Year Plan $\left(10^{\text {th }}\right.$ FYP) and currently active National Agriculture Policy 2061 BS and Three Year Interim Plan have encouraged the cooperatives and private sectors for adoption of sustainable organic agricultural practices. Modern organic farming in Nepal is gradually increasing in terms of area coverage and production where various agricultural commodities are being produced organically and exported to the foreign market. There are about 26 organic farms registered up to 2005 covering about 45 ha of land while more than this land is estimated to be under organic farming practice as unregistered farms (Shakya, 2005). There are many farmers who are adopting the modern organic farming practices individually or through group and cooperative in Nepal but their database are not available. Among them, Organic Agriculture Producers Cooperative is probable the first cooperative in organic agriculture sector in Nepal where more than 80 farmers are organized and are adopting the organic farming practice and supplying the produce to the local and national market. Organic Agriculture is cost effective, affordable and does not require expensive technical investment but provides more employment opportunity. It is a viable solution to preventing global hunger by providing comparatively higher yields from low input agriculture in food deficit regions (Lue, 2004).

Comparative profitability of conventional or inorganic and organic agricultural production practices varies due to wide range of production methods used in different regions and with different crops, and because of the variable organic price premiums (Cook et al., 1989). In most instances, costs per unit area are generally, but not always, higher for conventional methods. The profitability of organic methods usually depends on price premiums. In a study of grain farms, Cacek and Langner (1986) found that organic farming equaled or exceeded conventional farming in economic performance. Similarly, Scialabba (2006) found that the productivity of organically grown carrot yield is found higher (27.97ton/ha) than that of inorganically grown carrot (26.30 ton/ha).

Some people view organic farming as a primitive, inefficient method but today's organic farmers utilize some of the latest technologies including genetically superior plants,

1 Program Officer, SECARD Nepal, Phone 014387199/9841580307, Email: rajkadhikari@gmail.com 
biological pest controls and advanced mechanization. In some situations organic farmers may be less vulnerable to natural and economic risks than conventional farmers since their systems are usually more diversified (Olson et. al., 1982). It is claimed that the widespread adoption of organic farming methods could result in rural revitalization, regional self-sufficiency in food production and changes in the existing "capital-intensive structure of agriculture".

Carrots (Daucus carrota var. sativus) have been successfully produced and marketed in Chitwan for the past 20 years especially for fresh consumption in salads. It is grown in cool winter season after harvest of rice in low lands while after maize in rainfed upland areas. Since last 4/5 years, both organic and inorganic carrot production system is common in Chitwan however the market is same for both categories of the carrot. Despite the lack of separate market and premium price for good quality organic carrot, farmers are encouragingly practicing organic production system. This study was intended to compare the cost associated with different factors of production and the return from organic and inorganic carrot production system in the region.

\section{METHODOLOGY}

This study was mainly based on primary information collected from the farmers of Phoolbari, Shivanagar and Mangalpur Vilage Development Committees (VDCs) of Chitwan district of Nepal. Those VDCs were purposively selected for the study due to availability of organic and inorganic carrot growers. Sampling frame was prepared from key informants interview and record of Organic Agriculture Producers Cooperative, Chitwan. Out of 55 organic carrot growers from three VDCs, 30\% from each VDCs were selected as study sample by using simple random sampling method. For comparison, equal numbers of inorganic farmers were taken from each VDC.

Table1. Population and sample of organic and inorganic carrot growers

\begin{tabular}{|c|c|c|c|}
\hline \multirow[t]{2}{*}{ Area } & \multicolumn{2}{|c|}{ Organic } & \multirow{2}{*}{$\begin{array}{c}\text { Inorganic } \\
\text { Sample }\end{array}$} \\
\hline & Population & Sample & \\
\hline Phoolbari & 40 & 12 & 12 \\
\hline Shivanagar & 9 & 3 & 3 \\
\hline Mangalpur & 6 & 2 & 2 \\
\hline Total & 55 & 17 & 17 \\
\hline
\end{tabular}

Primary information was collected by using pre-tested interview schedule, applying faceto-face interview method. The collected information were first tabulated, coded and entered onto computer. All the local measurements were converted into standard unit and final analysis was done by using computer software packages: Microsoft Excel and Statistical Package for Social Science (SPSS).

\section{COST OF PRODUCTION AND GROSS MARGIN}

Carrot is a short duration crop and does not require fixed cost bearing inputs except land. So, sum of total variable costs was assumed as total cost of production and it was calculated by using following formula.

$C_{p}=C_{\text {seed }}+C_{\text {fert }}+C_{\text {tillage }}+C_{\text {labor }}+C_{\text {others }}$

Where,

$C_{p}=$ cost of production 
$C_{\text {seed }}=$ cost on seed

$C_{\text {fert }}=$ cost on fertilizer

$=\left[\right.$ cost on organic fertilizer $\left(C_{o f}\right)+$ cost on inorganic fertilizer $\left.\left(C_{i o f}\right)\right]$

$C_{\text {tillage }}=$ cost on tillage operation

$=\left[\right.$ cost on bullock $\left(C_{b}\right)+$ cost on tractor $\left.\left(C_{t}\right)\right]$

$C_{\text {labor }}=$ cost on human labor

$=\left[\right.$ cost on male labor $\left(C_{m l}\right)+$ cost on female labor $\left.\left(C_{f l}\right)\right]$

$C_{\text {others }}=$ cost on other inputs like herbicides, growth regulators, packaging, and transport

The gross margin is the difference between the gross return and the total variable cost incurred i.e.

Gross margin $=$ Gross return - total variable cost

\section{BENEFIT COST RATIO ANALYSIS}

Benefit cost ratio is the ratio between gross margin and total cost of any enterprise. In this study, benefit cost ratio was calculated by using the formula:

$$
B / C \text { ratio }=\frac{\text { Gross } m \arg i n}{\text { Total } \cos t}
$$

\section{RESULT AND DISCUSSION}

\section{COST ANALYSIS}

Comparing the cost on different inputs by production system, per hectare cost on tillage operation was lower in organic production system but cost on bullock was significantly higher (NRs. 11295.06/ha) than inorganic system (NRs. 8221.90/ha). On the other hand, cost on tractor use was significantly higher in inorganic system (NRs. 13622.05/ha) than organic system (NRs. 7538.97/ha). Only organic fertilizes were used in organic production system while both organic and inorganic fertilizers were used in inorganic production system. Comparing the cost on fertilizers, per hectare cost on organic fertilizer was significantly higher (NRs.26302.73) in organic production system and cost on inorganic fertilizer was found significantly higher (NRs.6203.38/ha) in inorganic production system. However, per hectare total cost on fertilizer was found to be higher in organic production system (NRs.26302.73) than that of inorganic system (NRs.21770.91).

The study showed that per hectare cost on seed was found significantly higher in inorganic production system (NRs.14743.87) than organic production system (NRs.12230.04). Similarly, per hectare cost on labor was higher (NRs.31630.35) in organic production system than inorganic production system (NRs.32054.82) within which female labor cost was higher in organic production system and male labor cost was higher in inorganic production system. Cost on other inputs like herbicides, growth regulators and growth promoting hormones was found to be significantly more in inorganic production system (NRs. 4442.15/ha) than organic production system (NRs.1409.66/ha). 
Table 2. Contribution of different cost items to total cost of carrot production (NRs/ha)

\begin{tabular}{lrrr}
\hline Cost items & Organic system & Inorganic system & \multicolumn{1}{c}{ t-statistics } \\
\hline Tractor cost $\left(C_{t}\right)[\mathrm{a}]$ & 7538.97 & 13622.05 & $-2.984^{*}$ \\
Bullock cost $\left(C_{b}\right)[\mathrm{b}]$ & 11295.06 & 8221.90 & $2.316^{*}$ \\
Total tillage $\left(C_{\text {tillage }}\right)[\mathrm{c}=\mathrm{a}+\mathrm{b}]$ & 18834.03 & 21843.96 & -1.387 \\
Organic fertilizer $\left(C_{\text {of }}\right)[\mathrm{d}]$ & 26302.73 & 15567.52 & $4.627^{*}$ \\
Inorganic fertilizer $\left(C_{\text {iof }}\right)[\mathrm{e}]$ & 0.00 & 6203.38 & $-17.721^{*}$ \\
Total fertilizer $\left(C_{\text {fert }}\right)[\mathrm{f}=\mathrm{d}+\mathrm{e}]$ & 26302.73 & 21770.91 & 1.929 \\
Seed $\left(C_{\text {seed }}\right)[\mathrm{g}]$ & 12230.04 & 14743.87 & -1.829 \\
Male labor $\left(C_{m l}\right)[\mathrm{h}]$ & 5505.35 & 6834.05 & -1.568 \\
Female labor $\left(C_{f l}\right)[\mathrm{i}]$ & 26125.00 & 25220.76 & .715 \\
Total labor $\operatorname{cost}\left(C_{\text {labor }}\right)[\mathrm{j}=\mathrm{h}+\mathrm{i}]$ & 31630.35 & 32054.82 & -.359 \\
Other cost $\left(C_{\text {other }}\right)[\mathrm{k}]$ & 1409.66 & 4442.15 & $-4.56^{*}$ \\
Total Cost of production $(C p)$ & 90406.84 & 94855.73 & -1.156 \\
[C $\left.C_{\mathrm{p}}=\mathrm{c}+\mathrm{f}+\mathrm{g}+\mathrm{j}+\mathrm{k}\right]$ & & & \\
\hline Note: figures $i n$ parenthesis indicate & & &
\end{tabular}

Note: figures in parenthesis indicate the percentage

*significant at $95 \%$ level of confidence $(P \leq 0.05)$

\section{RETURN ANALYSIS}

From the study, it was found that carrot production was 284.85 quintal per hectare in organic system which was insignificantly lower than that of inorganic production system (i.e. 290.71Q/ha). Average per unit price for both organic and inorganic carrot was found equal i.e. NRs. 798.52 /quintal. Per hectare revenue from carrot production was found to be lower in organic system (Nrs. 227832.77) than that from inorganic system (NRs. 231383.58) though the difference is insignificant. In contrast to production and revenue, higher gross margin was found in organic production system (NRs.137425.92/ha) than inorganic production system (NRs.136527.84/ha).

Table 3. Comparison of output and revenue in organic and inorganic carrot production

\begin{tabular}{llll}
\hline Particulars & Organic & Inorganic & t-statistics \\
\hline Production (Q/ha) & 284.84 & 290.71 & -.387 \\
Average price & 798.52 & 798.52 & 0.00 \\
Revenue (NRs/ha) & 227832.77 & 231383.58 & -.226 \\
Gross margin (NRs/ha) & 137425.92 & 136527.84 & .074 \\
\hline
\end{tabular}

\section{BENEFIT COST RATIO ANALYSIS}

Benefit cost ratio is the quick and easiest method to determine the economic performance of farm business. Though, average total cost, average production and average total revenue were higher in inorganic production system, the gross margin i.e. difference between average revenue and total cost is higher in organic production system. From this study, higher benefit cost ratio was found in organic carrot production system (1.52) than that of inorganic carrot production system (1.44). 
Table 4. Benefit cost ratio analysis of organic and inorganic carrot production

\begin{tabular}{lrr}
\hline Particulars & Organic & Inorganic \\
\hline Gross margin (NRs./ha) & 137425.92 & 136527.84 \\
Total cost (NRs./ha) & 90406.84 & 94855.73 \\
Benefit-cost ratio & 1.52 & 1.44 \\
\hline
\end{tabular}

\section{MARKETING}

From the study, it was found that there were no separate market, marketing channel, marketing system and premium price for organic carrots. Therefore, both organic and inorganic carrot follows the same marketing system. Selling of carrot from the farm gate to the contract buyers was most commonly practiced followed by selling to wholesale market. Contract buyers transport carrot right from the field. While in selling to wholesale market, farmers transport the produce by cycle, tractor or auto. Following was the most common marketing channel for both organic and inorganic carrot marketing for the study site.

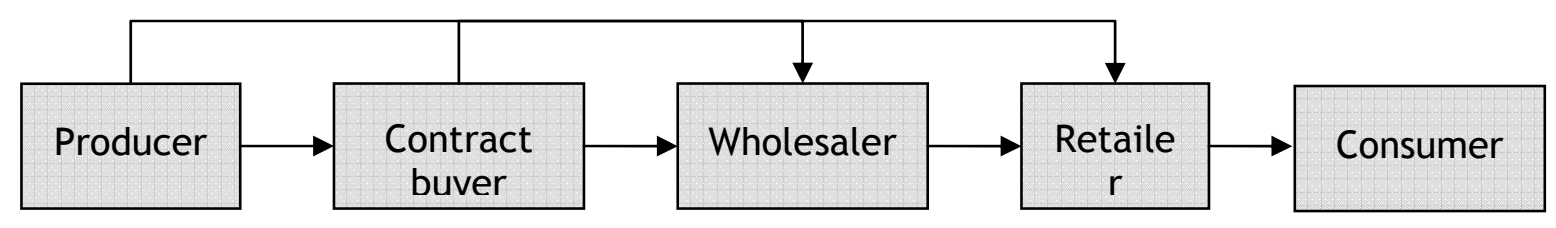

Figure1. Marketing channel of carrot in Chitwan

\section{CONCLUSION}

This study revealed that growing carrot is a remunerative and successful agro-enterprise during cool winter season in Chitwan district of Nepal. While comparing the organic and inorganic carrot production system on per unit area basis, cost of production, productivity and gross revenue was higher in inorganic system which favors the adoption of inorganic agricultural practices. But, In contrast with these figures, higher gross margin (or profit margin) in organic production system suggests for the adoption of organic farming practice for carrot production. More than this, from economic view point, higher benefit cost ratio in organic production system recommends for widespread adoption and commercialization of it. In short, this study concludes that adoption of organic carrot production is economically profitable and holds comparative advantage than inorganic production system. Thus, adoption of organic carrot production system is recommended. On the other hand, governments policy and plan for separate market establishment and fixing the price premium are also recommended for wider adoption of organic agricultural practices in general and organic carrot production in particular.

\section{ACKNOWLEDGEMENTS}

I would like to acknowledge the entire farm households of the study site for their cooperation in field study. Organic Agriculture Producers Cooperative personals are highly acknowledged for providing relevant information. My dear colleague Ms. Deepti Uprety is especially thankful for her contribution in this study. My co-workers at SECARD Nepal are thankful for their nice cooperation during the study period. 


\section{REFERENCES}

Cacek, T. and L.L. Langner. 1986. The Economic Implications of Organic Farming. American Journal of Alternative Agriculture. 1(1): 25-29.

Cook, R., K. Norris and C. Pickel. 1989. "Economic Comparison of Organic and Conventional Production Methods for Fruit and Vegetables." University of California, USA. http://www.sustainable.tamu.edu/publications/organicproduce/organic.html. Retrieved on 02 March 2006

IFOAM, 2005. More than 26 million certified organic hectares worldwide. Press release. International Federation of Organic Agriculture Movements (IFOAM), [online] www.ifoam,org/press/pdfs/pm-weltweit-englisch.pdf. Retrieved on 12 August, 2007.

Leu, A. F. 2004. Organic Agriculture Can Save the World. Well Being Journal 13(2) [Online] www.wellingbeingjournal.com/articles.html. Retrieved on 02 March 2007.

Olson, K.D., J. Langley and E.0. Heady. 1982. "Widespread Adoption of Organic Farming Practices: Estimated Impacts on U.S. Agriculture." Journal of Soil and Water Conservation. 37 (1): 41-45.

Shakya, D.B. 2005. Organic Products: International Market, Proceedings of National Workshop on Organic Agriculture and Food Security. Nepal Permaculture Group, Kathmandu, Nepal, December 13-15, 2005.

Scialabba, N. 2006. Organic Agriculture Perspectives. Conference on Supporting the Diversification of Exports in the Latin America and Caribbean Region through the Development of Organic Agriculture. Port-of-Spain, 8-10 October 2001available: http://www.fao.org/sd/index_en.htm 